\title{
Imágenes nómadas transnacionales. Análisis crítico del discurso del cine ecuatoriano.
}

\section{Transnational nomadic images. Critical analysis of the discourse of Ecuadorian cinema. Imagens nômades transnacionais. Análise crítica do discurso do cinema equatoriano.}

\author{
Karolina Romero Albán ${ }^{1}$ \\ Universidad San Francisco de Quito (Ecuador) \\ karolinaromero30@gmail.com
}

Fecha de recepción: 10 de agosto de 2019

Fecha de recepción evaluador: 15 de septiembre de 2019

Fecha de recepción corrección: 09 de octubre de 2019

El libro "Imágenes nómadas transnacionales. Análisis crítico del discurso del cine ecuatoriano" de Iván Rodrigo, editado por la Universidad Andina Simón Bolívar en 2019, merece de antemano un franco reconocimiento, pues, escribir un libro de metodología, y más aún de metodología de análisis del cine, no resulta tarea fácil, y tampoco es algo que

\footnotetext{
${ }^{1}$ Doctora en Ciencias Políticas y Sociales, UNAM. Líneas de investigación: dimensiones socio-políticas del arte, cine y política, cine latinoamericano; en el marco de la sociología del arte, los estudios culturales y los estudios de cine. Autora del libro: El cine de los otros: la representación de "lo indígena" en el cine documental ecuatoriano (FLACSO-Ecuador, 2011). Colaboró en la investigación Reinventando al otro: El documental indigenista en el Ecuador (Consejo Nacional de Cine del Ecuador, 2010). Miembro del Comité Editorial de la Revista de Estudios de cine La Región Central del Instituto de Investigaciones Estéticas de la UNAM. ORCID: https://orcid.org/0000-0002-4472-9130
} 
ocurre a menudo, como podemos confirmar los investigadores y estudiosos del cine en Ecuador.

En este sentido, este libro, sin duda, constituye una contribución significativa para los estudios de cine, pues, existe un vacío notorio sobre cuestiones metodológicas en la bibliografía del cine latinoamericano. Por eso también, es necesario señalar el papel de las editoriales académicas, como la UASB, en la apertura para este tipo de propuestas que enriquecen el campo de los estudios y la investigación del cine ecuatoriano.

El texto de Rodrigo representa un aporte necesario para estudiantes que inician investigaciones sobre cine, y análisis del discurso de medios en general, puesto que presenta un recorrido exhaustivo, respecto a la teoría de la representación y del discurso, que ubica los principales debates en estos ámbitos. Además, considero que uno de los puntos más relevantes, para los investigadores, es la aproximación a la práctica de construir estrategias metodológicas relacionadas con el campo del análisis del discurso. El libro resulta un claro ejemplo de cómo se construye la metodología, pues, muestra las costuras del análisis y esto, sin duda, contribuye y enriquece la práctica de la investigación.

Es decir, el texto constituye una referencia que ayudará a entender de forma didáctica cómo se construyen las categorías de análisis, pues, pone de manifiesto cómo operan las estrategias y herramientas metodológicas dentro de un campo específico.

El libro inicia definiendo el marco conceptual, desde donde parte la propuesta metodológica de análisis crítico del discurso, que construye el autor. Esta aproximación requiere, de entrada, un esfuerzo importante por parte del lector, pues, expone conceptos complejos que el autor procura articular teniendo como eje el problema de la representación y su teorización, desde varias disciplinas de las ciencias humanas. La densidad de conceptos se discute a través de varios pensadores cercanos a la teoría de la imagen, estudios culturales, estudios visuales, filosofía y antropología.

En este sentido, me referiré a dos conceptos que considero son las más interesantes, dado el tratamiento que les otorga Rodrigo, para construir su propuesta metodológica.

Uno es el concepto de ekphrasis que lo trabaja de la mano de W.J.T. Mitchell, y, el segundo tiene que ver con su propuesta de análisis del "espectador crítico", ubicándose en el campo de los estudios visuales y buscando intersecciones entre éstos, el análisis del discurso y la teoría de la representación.

El autor destaca el concepto de ekphrasis como la "representación verbal de una representación visual", es decir, se plantea el complejo problema de cómo hacer visible el sentido de la representación mediante el lenguaje. Este concepto lo despliega hacia el plano del discurso audiovisual, para analizar cómo se establecen las figuras de otredad y diferencia en el cine de temática de migración en un corpus de películas ecuatorianas. 
No obstante, me parece que este concepto se vuelve clave para la definición que se trabaja, posteriormente, de representaciones visuales como prácticas de producción de sentido, las mismas que comprenden las prácticas discursivas que involucran tanto las que se articulan en el filme, entendido como texto, como las del espectador, entendidas como especulares. Esta idea de prácticas de producción de sentido permite entender las películas como objetos culturales, es decir, propone pensar cómo se construye visual y narrativamente la representación de la migración en el cine ecuatoriano $\mathrm{y}$, de este modo, se ubica en el plano de la construcción simbólica de procesos sociales.

Al respecto, me parece acertada su aproximación al cine como construcción social, definiéndolo como práctica cultural que implica lo escópico y el discursivo. De este modo, el autor plantea la interrogante acerca de cómo se configuran las representaciones visuales de la migración en el cine ecuatoriano, proponiendo entender los filmes como "objetos de la representación" mediante su propuesta de método propio: la deconstrucción audiovisual y narrativa de la representación del migrante en el cine ecuatoriano de la primera década de los años 2000.

De allí se desprende el segundo concepto de mediaciones socioculturales, que involucra la práctica de la representación, desde el punto de vista del espectador. Según el autor, esta indagación implica "el desmantelamiento de los procesos de subjetivación del espectador como consumidores de imágenes" (Rodrigo, 2019, p. 15).

No obstante, el autor establece un diseño que reconoce tres niveles para analizar los filmes: 1. el texto fílmico, 2. la posición del espectador y 3. el espacio que concierne la producción, es decir, al emisor. En este sentido, la metodología trata de articular estos tres niveles, entendiendo:

- el texto fílmico: como el discurso, lugar de enunciación y la episteme.

- el espectador: involucra la mediación socio-cultural.

- el emisor: se refiere a la intención, la forma de ver y representar del emisor pero que es diferente al discurso de la película.

Desde mi perspectiva, la propuesta metodológica respecto a "la experiencia del espectador crítico", como la denomina el autor, constituye quizá la cuestión más novedosa del texto. Podría decirse que Rodrigo construye una metodología de la mediación, que establece la problemática del cine de migración como práctica cultural.

A través de la mediación, el autor reconoce las representaciones de la migración en el cine ecuatoriano como prácticas sociales de visualidad. Esto lo hace preguntándose ¿cómo se produce el sentido en el espectador?, planteando que el hecho de pensar las prácticas de visualidad y representación "no sólo implica la construcción social de la visión sino que tiene que ver con la construcción visual de lo social" (Rodrigo, 2019: 48).

Finalmente, considero importante destacar esta idea de la "construcción visual de lo social", pues, el análisis profundo de las representaciones sobre migración, 
problematiza la manera cómo se construye visualmente el asunto de la migración en el cine ecuatoriano. En este sentido, me parece que dicha aproximación se relaciona con los planteamientos de Mitchell, en la medida que para éste, en última instancia, las imágenes activan procesos de mediación, los mismos que conciernen una dimensión histórica que ubica al sujeto espectador en relación con su tiempo.

Justamente, el análisis crítico del discurso que propone Iván Rodrigo pone en evidencia que las representaciones de la migración, en el cine ecuatoriano, implican sistemas de conocimientos que configuran al cine como una práctica social, a partir de lo cual lo define como:

- cine posmoderno: se funda en un presente sin pasado.

- cine no nacionalista: no muestra valores tradicionales de la nación.

- cine que promueve una visión de libre movilidad en el mundo global: la movilidad como un derecho.

- cine con matriz decolonial: pluralidad visual con estrategias que exploran nuevas subjetividades.

De este modo, el texto finaliza planteando una interrogante muy pertinente para la investigación sobre medios de comunicación: las nuevas subjetividades que configuran la diáspora actual latinoamericana no pueden ser pensadas bajo los esquemas tradicionales del discurso, es decir, su estudio también requiere nuevas interpretaciones desde las ciencias sociales, es allí donde se posiciona el trabajo de Iván Rodrigo. 